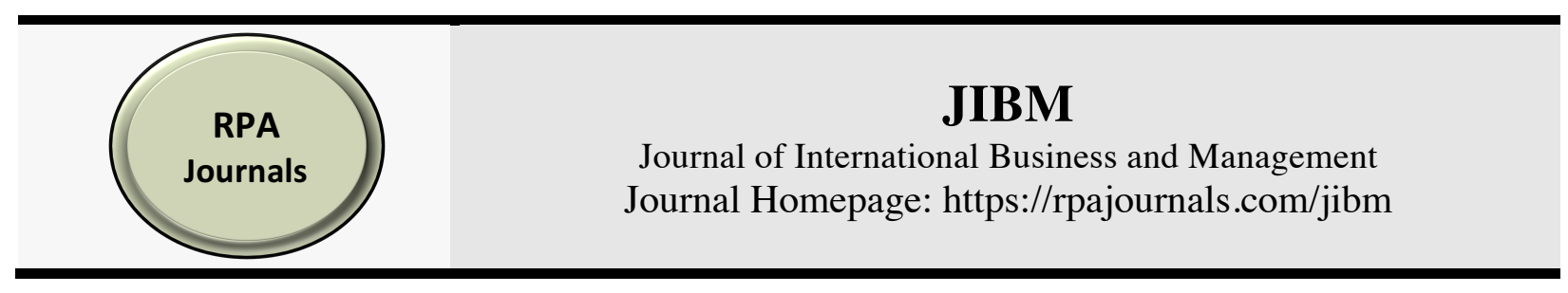

\title{
Economic Consequences and Overall Implications of Bhartiya Janata Party (BJP) Rule in India during 2014-19
}

\author{
Dr. S. K. Sharma \\ Mahatma Jyotiba Phule Rohilkhand University, Bareli, India \\ Veer Bahadur Singh Purvanchal University, Jaunpur, India
}

\begin{abstract}
Not all popular governments that are formed prove to be good for the economy. The present government is no exception to this. The tall election campaign promises of employment generation and removal of black money, among others, brought Bhartiya Janata Party (BJP) in power in 2014. But the government failed miserably on economic fronts. The lowest India's growth rate of 5\% may be attributed to failure of monetary and fiscal policy that culminated into demonetization and excessive rise of Non-Performing Assets (NPA). The paper examines the false promises of welfare to the people by the BJP government and yet sustaining the same by political manoeuvrability in 2019. The erstwhile United Progressive Alliance (UPA) government did much better on economic fronts, but it failed in reaching to the people. If the BJP government does not revert to fulfilling its promises which perhaps is very difficult now, there would be accentuation of poverty and unemployment in India.
\end{abstract}

Keywords: Government, Bhartiya Janata Party (BJP), United Progressive Alliance (UPA), Poverty, Unemployment, India

*Corresponding author: Dr. S. K. Sharma; Email: surendra194@gmail.com

DOI: https://doi.org/10.37227/aricon-2019-jibm-9

\section{Introduction}

Not all popular governments that are duly elected prove to be good for the economy. The present Modi Government in India is no exception to this. This government which was formed in 2014 was formed in the background of tall election campaign promises of employment generation of 20 million per annum, removal of black money from the economy, end of rampant corruption, streamlining of procedures for investments both private and foreign in the economy, and among others promotion of infra-structural facilities to the farmers. The BJP laid emphasis on inclusive development by the most popular slogan "One India, Best India - Unity and Development of all" (BJP Manifesto, 2014). This manifesto was not different from the UPA which called for "Empowerment of each hand for progress" (INC, 2014).They introduced the GST (Goods and Services Tax) which is called "one nation, one tax and one trade" in July 2017. It was actually the brainchild of the UPA government as envisaged in Section 155 of the budget speech of Finance Minister of 2006-07 intended to be introduced from 2010 (The Economic Times, February 28, 2006). The BJP which had earlier opposed the GST adopted it without proper thought; thereby making very complicated procedures of registration, return filing, and irrational four tier structure of tax rates $(5 \%, 12 \%, 18 \%$ and $28 \%)$ of 1211 items (GST Council, 2017). The oil and petrol was not included into the GST as there was 
deliberate attempt by the government to deprive the common people the benefits of declining international oil prices. It was stated that the revenue generated by the declining international oil prices would be used for development. The price of petrol and diesel is much higher than what the UPA government gave to people during 2009-2014. Millions of youths in unorganized and manufacturing sector were thrown out of jobs due to demonetization. One estimate of National Sample Survey Office's Periodic Labour Force Survey states that around 5 million people lost their jobs during 2016-18; job crisis began to worsen. Unemployment was at 45 year high of $6.1 \%$ in $2017-$ 18 which was the reflection of adverse impact of demonetization (MOSPI, 2019).

Compared to this, during UPA Government 2009 to 2014, the GDP was in the range 5.4\% to $5.9 \%$ in spite of the global recession of 2008. Yet, the agriculture sector during 2013-14 grew more than $4.7 \%$. Balance of payments had improved drastically as current account deficit came down from US $\$ 88.2$ billion in 2012-13 to US $\$ 32.4$ billion in 2013-14. There was record high food production of 264.4 million metric tons and oil seeds 32.4 metric tons. India had second fastest growing services the CAGR at 9\% just below China 10.9\% during 2011-12 (The Hindu, 2014).

Such feat has not been achieved by the Modi government. The so called digitization without a proper planning to integrate the common people in opening of accounts has come as a stumbling block in inclusive development. The government introduced electoral bonds and amended "Foreign Contribution Regulation Act" that pumped black money into its party's coffer (Ministry of Home Affairs, 2015). The election commission virtually failed in controlling the flow of money in the election campaign except somehow administering the conduct of election procedures. Media houses were funded enough to make Modi's face prominent in all its programmes. Loans of defaulter corporate houses were written off ' 2.4 lakh crore in three years, and in return the corporate houses donated to the party fund (Business Today, 2018). The NPAs of 27 Public Sector Banks increased from $12 \%$ to $140 \%$ during the last two years. The total NPA is ` 17.55 lakh crore (US\$218.4 billion) as on 31 st March 2019 (Ministry of Finance, 24 June 2019). As per the recent estimate, in the second quarter of 2019-20, our economy advanced by $5 \%$. This has slowed down from the earlier position of 5.8\%. This is the weakest growth rate since the first quarter of 2013 owing largely to a slowing down of manufacturing and construction sectors.

It is also not out of context to state that in the first quarter of 2010, there was record highest growth of GDP of $11.4 \%$ in UPA government. Now, the state of economy is "deeply worrying" (Singh, Manmohan Sept 01, 2019). India has the potential to grow at a much faster rate, but mismanagement by the present government and hastily implemented GST has resulted in this slow down. Lesser known Infrastructure Leasing \& Financial Services Limited (IL\&FS) founded in 1987 that operated through more than 250 subsidiaries collapsed in September 2018, and it had defaulted 90,000 crore (US\$12.64 billion) (Anand, 2018).

Under this background of macroeconomic scenario, attempt has been made to examine all the important factors viz. monetary policy, fiscal policy, savings and investment, balance of payments position, unemployment and poverty, and welfare measures that played key role in economic slump of India during 2014-19. E-governance and ease of administration followed by some disturbing factors that threaten the democratic and federal structure of our constitution have also been taken due care to justify the overall implications. For statistical data, we have consulted government sponsored authentic reports and standard websites.

\section{Monetary Policy}

Unplanned monetary expansion and contraction leads to inflation and recession thereby aggravating purchasing power and unemployment. The Reserve Bank of India, at the behest of Government of India, demonetized the higher denomination of Re500 and Re1000 in November 2016. The sum of currencies of ' 500 and ' 1000 constituted $80 \%$ of total money supply in the economy. The replacement of the demonetized notes by fresh ` 500 and ' 2000 was much slower than expected. This was the most severe blow to the economy ever done by erstwhile governments of India by announcing demonetization. Naturally, India where a large section is unorganized and which is devoid of banking sector, the nation suffered most. Since there was drastic cut in supply of money without proper 
replacement, most of wage earning people of unorganized and manufacturing sector were thrown out of jobs. Its impact is still being seen as most of savings in the form of denomination of " 500 and ' 1000 of poor people were snatched away easily. It may be noted that most of poor and low wage earners do not have any account in banks. The clear cut mandate of demonetization was to curb black money, corruption and check counterfeit currency from the economy. The total value of notes demonetized was '15.41 lakhcrore (US\$220.14 billion). Out of the above, '15.31 lakh crore (US $\$ 218.72$ billion) was returned, thereby just $` 10,720$ crore (US $\$ 1.42$ billions) of junked currency did not return in the banking system. In order to bring out normalcy in the supply of money the RBI spent ' 7965 crore (US\$1.14 billion) in 2016-17 on printing of new notes of 500 and ' 2000 and other denominations which was more than double the amount ${ }^{`} 3471$ crore (US\$0.496 billion) spent in previous year. In 2017-18, the RBI spent another 4912 crore (US\$0.70 billion) on printing of currency notes (RBI, 2018). As the demonetization was an utter failure, to be precise, '12,877 crore (US \$1.84 billion) could have been saved for other development works. The demonetization had other severe impacts of deprivation of one's own savings in time of crisis or social events.

During this regime as the NPA got increased to an alarming position, the banks are deprived of cash for loaning to their consumers for economic activities. In order to bridge the gap of fiscal deficit, the Government put pressure on RBI to provide its surplus reserve money to it. The government is of the view that buffer stock of $28 \%$ of RBI is much above the global level of $14 \%$ (Economic Times, 2019). Hence, the surplus over and above the standard accepted norm should be transferred to the government. An Economic Capital Framework led by former RBI governor, was formulated in December 2018 to recommend transfer of surplus resources to the government in 90 days. As per the recommendation, the RBI has transferred '1.76 lakh crore (US\$25.142 billion) to the government in August 2019 (RBI, 2019). For the first time in 84 years of history of formation of RBI Act 1934, this situation has emerged when the government under section 7(1) of RBI has tried to exercise its power.

\section{Fiscal Policy}

This relates to the revenue earning, taxation and welfare programmes of the government. In order to ameliorate the conditions of people and provide employment, the government is always under pressure of limited revenue and unlimited expenditure. Fiscal Responsibility and Budget Management Act, 2003 suggests a gap of 3\% of GDP as the ideal target (Ministry of Finance, 2003). Government typically finances the deficit by borrowing from banks, public institutions, printing additional money and even from overseas investors. In 2013, the fiscal deficit was $4.5 \%$ of GDP. In 2014-19, the fiscal deficit has been maintained to be below 4\%. In 2014-15, the fiscal deficit was $4.1 \%$. It came down to $3.9 \%$ in 2015-16. It further came down to $3.5 \%$ in $2016-17$, and then to $3.5 \%$ in 2017-18 and finally to $3.5 \%$ in 2018-19. Here, the BJP government has an upper hand in maintenance of fiscal deficit as compared to the UPA of 2009-14. The fiscal deficit was under control as there was decline of international oil prices, but the internal price was kept higher in order to generate government revenue. Again, GST was introduced in 2017 which boosted revenue. During the NDA regime, tax to GDP ratio increased as compared to the UPA government. Moreover, there was more returns and better tax compliance. Dividend and disinvestment receipts were higher than the UPA government. There was significant decline in food prices in 2017-18 due to bumper food production of rabi and kharif crops. The prices of pulses were comparatively cheaper. In the UPA government, there was worst drought in 2009 when the monsoon rainfall was $22 \%$ lower than the long term average. In case of GST, even after two years of its formation, the people are not able to file returns owing to its most complicated procedures (Raghavan, 2019). In the Union budget 201920 , the tax rates have been hiked. Already the Indian economy is under high rates of taxation. The government should understand that after an optimal level, raising tax rates is inimical to growth in revenue and hence inimical to economic growth (Laffer, 1979). Here, the government wants to reduce the Fiscal Deficit to 3.3\% of GDP (Ministry of finance, 2019). In the union Budget 2019-20, the FD is proposed to be 7.03 lakh crore (US\$98.67 billion). This is to be checked by government borrowing. Overseas borrowing shall meet out $10 \%$ of this FD, thereby leaving around 6.33 lakh 
crore (US $\$ 88.85$ billion) to be met from the private sector. At present, the government is under tremendous pressure to somehow raise the revenue and meet the NPA of banks. Recently, the repo rate of RBI has been reduced and accordingly, the banks are required to lower down their interest rate to boost confidence among investors. Unfortunately, the interest rate of savings has been reduced and further, interest rates of fixed deposit ratios have also been lowered. The government institutions are now charging higher prices for their services but without quality improvement. An interesting example of such institution is the recent motor vehicle act where-in they raised the fees exorbitantly inviting enough scope for corruption. Most of PSBs are now merged and through this merger the surplus staff is being removed. The BSNL (Bharat Sanchar Nigam Limited), government owned PSU, is in the financial crunch, it could not disburse salary to its employees for over seven months, wants to lay off $30 \%$ of its contract employees in Kerala (The Hindu, September 9, 2019). Government is dis-inventing many of sick public sector units to check the deficit of revenue.

\section{Balance of Payments}

For developing country like India, balance of payments position has always been one of major constraints of development. Since most of India's resources are used in meeting the import bills of oil, a small amount remains for meeting other developmental activities. The BoP during 2014-19 is on rising side. The UPA government gave a most favorable BoP positions to the NDA government. Both the government and RBI jointly improved the BoP position in 2013-14 and dramatically the trade balance improved as export of merchandise increased and there was moderation of import of gold. The CAD (Current Account Deficit) declined sharply from a record high of US\$88.2 billion which was $4.7 \%$ of GDP in $2012-13$ to US $\$ 32.4$ billion (1.7\% of GDP) in 2013-14.The CAD increased to $2.1 \%$ of GDP in 2018-19 from $1.8 \%$ in 2017-18 owing largely to increase in trade deficit. Net flow of FDI in 2018-19 was US\$30.7 billion. This was marginally higher than US\$30.3 billion in 2017-18. Portfolio investment recorded a net outflow of US\$2.4 billion in2018-19, as against the inflow of US\$22.1 billion in 2017-18. Again, there was a depletion of foreign exchange reserves to the tune of US\$3.3 billion in 2018-19 (RBI, 2019). In order to meet the adverse balance of payments position, the government has introduced sovereign bonds similar to Indonesia, Turkey, Africa and Latin American countries. India is among the lowest globally as the sovereign external debt to GDP is less than $5 \%$ (Roy, 2019). The government may desire to set this target of sovereign bonds to $6 \%$ of GDP.

\section{Savings and Investment}

In 2010-11, the ratio of gross capital formation (GCF) to GDP at current prices had risen to a peak level of $39.8 \%$. Thereafter, this GCF fell down to $30.9 \%$ in 2016-17. A modest recovery took place in the following year 2017-18, but the peak level could not be sustained in 2018-19. The overall saving rate has declined to $30 \%$ in $2016-17$ from $34.6 \%$ in $2011-12$. The worst fall was seen in the household sector which is the largest contributor to savings in the economy. The savings of household sector dropped from $23.6 \%$ in 2011-12 to $16.3 \%$ in 2016-17(World Bank, 2017). If household savings continue to decline, it would put a serious challenge to the GDP growth and macroeconomic stability and give an adverse impact on unemployment and poverty. Household provide more than $50 \%$ of savings in the economy followed by private corporations and public sector. As the FDI is coming down, the government has eased FDI rules in retail in order to attract increased foreign direct investment into India. Earlier companies of single brand retail with more than 51\% FDI needed 30\% of its goods from within India. With the new law, this $30 \%$ can be calculated over the last five years of its operations.

\section{Unemployment and Poverty}

Demonetization of currencies in November 2016 led to sudden fall in employment and lowering of income of people in general and wage earners in particular. This led to a slump in demand thereby leading to less of consumption and less of investment which in turn led to more unemployment. This has accentuated poverty among wage earners and marginal farmers. The automobile industry has 
been hard hit. It has thrown millions of people out of jobs. The reason behind this recession is liquidity crunch, increased prices of products due to regulatory measures, higher taxes and rise in insurance rates. According to Society of Indian Automobile Manufacturers (SIAM), during the last three months there has been cut of 0.2 million jobs due to slump in demand of automobile dealership (Sharma, 2019). The railways will retrench 0.3 million out of 1.3 million employees. Now all airports are being given to a select business houses in contravention of Monopolistic and Restrictive Trade Practices Commission (MRTPC) which was established in 2008 for promoting fair completion among stakeholders. There is again slump in Fast Moving Consumer Goods (FMCG) such as nondurable household goods like packaged foods, beverages, toiletries and other consumables in rural areas. Hindustan Lever has also shown deficit in demand (Shyam, 2019). The corporate sector during the last three quarters has shown unprecedented weakening of investment, not because of its borrowing capacity but because of fall in productivity owing largely to slump in demand. Even after reduction of interest rates by the central bank, the investment demand is not picking up. We do not find data on unemployment during 2014-19. There is only available data of NSS $68^{\text {th }}$ round of 201112 (NSSO, 2014).

\section{Digitization and Ease of Administration}

It was in UPA government that National E Governance Plan was launched in 2006. The present government launched digitization programme as flagship programme (Digital India, 2015). The objective of this e-Governance was to have inclusive growth in order to empower people digitally and share all the fruits of development. It is a highly advanced and complicated programme that depends upon viz. (a) Broadband High Ways (b) Universal access to mobile connectivity (c) Public Internet access Programme (d) Reforming Government through technology (e) Electronic Delivery of Services (f) Information for all (g) Electronics Manufacturing (h) IT for Jobs and (i) Early Harvest Programmes.

In a diverse country like India where there is dearth of quality education and public universities are deprived of internet and broadband facilities, to think of digitization is a very distant dream. Even the educated people are not comfortable with the e-governance. Although the general literacy level has gone up to $74 \%$, but the digital literacy is different. Thus, one can understand the fate of Digital India Programme when its adaptability at the ground level is concerned. Naturally, the demonetization gave a severe blow to such sectors which were deprived of basic facilities of egovernance. There are 190 million people who are unbanked in India in during 2014-17 (Global Findex, 2018). Although Jan Dhan Yojana of BJP brought 310 million people in the formal banking system, but it was found that almost half of accounts remained inactive.

\section{Welfare Measures}

There are flagship programmes of the Union Government which are approved by the Union cabinet or Development Evaluation Advisory Committee of the Planning Commission (DEAC). They are of utmost importance as they take care of health, education, environment, irrigation, rural and urban development, employment, and other sectors. Some other flagship schemes of this government are (i) Swachh Bharat Abhiyan launched on October 2, 2014, (ii) Digital India Programme launched on July 1, 2015, (iii) PM Surakshha Bima Yojana launched in 2015, (iv) PM Jan Dhan Yojana launched in August 2014, (v) Beti Bachao Beti Padhao, (v) PM Kausal Vikas Yojana (PMKVY), and (vi) PM Ujwala Yojana launched in May 1, 2016. These new programmes did influence the rural people, marginal farmers and wage earners which the BJP used as vote banks in the recent 2019 general election.

Inflation rate (Consumer Price Index) rose from 4.28\% in March 2018 to 4.92\% in June 2018. Thereafter, the inflation rate has gone down to $2.86 \%$ in March 2019 after touching the lowest inflation rate of $1.97 \%$ in January 2019. There is also inflation rate of consumer food price index (CFPI) which states that during the period CFPI was 2.81\% in March 2018 and it came down to $0.30 \%$ in March 2019 after negative inflation rate of 2.65\% in December 2018(MOSPI, 2019). In 
fact negative inflation rate started in October 2018. This was at the cost of farmers who were deprived of support in procurement prices of their products.

\section{Discouraging / Distorting Factors}

Institutional set up of economic data collection and their monitoring are undergoing some distorting trends. In recent times, government is failing in sending data to multilateral agency viz. IMF and others like special data dissemination standards. According to recent IMF's report on "Annual Observance Report of the Special Data Dissemination Standards for 2018", India failed to comply with multiple requirements (SDDS, 2018). Whereas other BRICS members viz. Brazil, China, South Africa \& Russia, have maintained a near impeccable record in the same period. The BJP government has scrapped the five year plans and done away with the Planning Commission. Now there would be fifteen year vision of development in tune with the global trends and economic growth. The Planning Commission has been replaced by NITI (National Institution for Transforming India) Ayog. The first Vision Document 2031-32, has come out which is in sync with UN's 2030 Sustainable Development Goals (Panagariya, 2017). This new vision has mandate to transform India into "a prosperous, highly educated, healthy, secure, corruption free, energy abundant, environmentally clean and globally influential nation" by 2031-32. Until determinants of growth and development are properly managed and coordinated, we shall not be able to achieve the target.

There has been exorbitant election expenditure by political parties. In 2019 general election, the expenditure was twice the expenditure done in 2014. The BJP alone spent ' 27000 crore (US\$3.8 billion). Such practice would put a genuine and common man away from seeking election as an independent candidate. There are attacks on long established federal institutions as there is interference by the governments. The Act of Right to Information has been diluted.

There is undue pressure and interference in administrative functioning of officials holding public posts. There are many instances of officials committing suicides and many resigning from their posts. One most recent example is one IAS officer from Karnataka who relinquished his post after making a statement that "it would be unethical on his part to continue in service when fundamental building blocks of our diverse democracy are being compromised in an unprecedented manner"(Jinoy, 2019). "Another incident is an arbitrary transfer of a chief justice of a High Court to a very smaller court, and thereafter following her resignation" is an affront to the judiciary (Mohammad, 2019). There were prevalence of fake news and their dissemination in election time. This made voters confuse while voting for the erstwhile general election. The Facebook, WhatsApp and twitter have not played a responsible role in dissemination of information. India so far does not have any law that takes action against fake news.

According to Prof. Irphan Habib (2019), the present government is distorting history of communal harmony and it is promoting 'rising communal feelings'. The present abrogation of Article 370 (which they did recently; gave special status to Jammu \& Kashmir) is nothing but to "create a communal divide". Having received an absolute mandate from the people, the government should see globally in providing welfares to the people. But, the most recent provision of $10 \%$ reservation to the economically weaker sections from the general category has led to constitutional crisis. This will be over and above the $50.5 \%$ of general category people leaving aside $15 \%$ for SC, $7.5 \%$ for ST and $27 \%$ for OBC out of $100 \%$ (Rautray, 2019)). The government should provide one uniform criterion of reservation in jobs and educational opportunities irrespective of caste and religion (Sharma, 2019).

\section{Factors Weakening Democratic Values}

Legacy of long-established social harmony is being eroded and there is constant effort to deharmonize the culture of universal brotherhood for their own interest to divide and rule. The present government does not recognize the foundation of all round developments laid down by the previous governments. Former President is reported to have said that India would become US\$5 trillion economy because of long established strong foundation led by previous governments (Mukherjee, 2019). The Central Government toppled many state governments which were duly elected. The 
opposition is reported to have alleged that the ruling government has put restrictions on freedom of speech and expression. Many righteous authors, freelance writers and journalists are reported to have been threatened of dire consequences. In 2018, the BJP government harassed and at times prosecuted activists, lawyers, human rights defenders, and journalists for criticizing authorities. Even draconian sedition and counter terrorism laws were used to target non-government organizations which were critical of government policies (Human Rights Watch, 2019). It is the beginning of an end of our democratic system by attack on citizenship, culture and universal brotherhood (Kumar, 2019). The government changed the term of reference of the $15^{\text {th }}$ Finance commission and mandated the panel to suggest ways for allocation of non-lapsable funds for defense and internal security (Narayanan, 2019). This should have been supported by the Chief Ministers of states of India. This is against the federal policy and against the cooperative federalism.

\section{Conclusions}

Among others, four most prominent factors that brought down the growth rate of India to the lowest $5 \%$ may be attributed to demonetization, the rise of NPA, the collapse of IL\&FS, and mismanagement of fiscal deficit, savings and investment behaviour. In the light of economic failures of the Modi government, a genuine question arises as to how the incumbent government again got a thumping majority in 2019, a much better feat than 2014. The government harped upon diverting the attention of people from economic agenda to other sectarian issues like social and communal divide. Religious issues were overplayed to divide the society into different segments viz. Hindus, Muslims, Sikhs and other minorities. Issues related with Jammu \& Kashmir and cross border terrorism were the main headlights of the election campaign of the BJP. So far, there has been no correlation between the inputs and outputs of data regarding votes cast in EVM. There were also indirect attempts by the government to weaken the democratic institutions by not adhering to established norms of balance between executive, legislature and judiciary. Here, Modi's politics has over ruled the economic failures of the government. In their election manifesto, there were resolves to fulfill the pledges. There is reference of "Future 2047" where there is vision of what India would be (BJP, 2019). For the BJP, 2019-24 is the foundation laying period for India of 2047. In addition to Ram Temple, Sabarmala Temple in Kerala is another addition in their manifesto. There are promises to protect the linguistic, cultural and social identity of the people of North East Hindus, Jains, Budhists and Sikhs escaping persecution from India's neighboring countries. Such people would also be given citizenship in India. National Registration of Citizenship would be extended to other states also like Assam. They already had mandate to abrogate Article $370(\mathrm{~J} \& \mathrm{~K})$ and $35 \mathrm{~A}$ which is now a fait accompli. They would also bring out Uniform Civil Code. More they bring out such legislations, more will there be polarization of votes in favour of the ruling party. The BJP government must understand that if the economic crisis becomes chronic as it is moving, there would be more unemployment and incidence of poverty. This deteriorating economic condition cannot be over tilted by the so called divisive forces. Therefore, the BJP would find the most difficult time to tide over the present scenario of economic recession in India.

The paper makes an attempt to examine in detail the false promises of welfare to the people by the BJP government and yet sustaining the same by political maneuverability at the cost of economy. The erstwhile UPA government did much better on economic fronts, but it failed in reaching to the people. Although, it had equally good manifesto (INC, 2019), but it could not highlight the economic failures of the BJP government. The media campaign of BJP was again at upper hand than that of the UPA. If the BJP government does not revert to fulfilling its promises which perhaps is very difficult now, there would be accentuation of economic crisis followed by poverty and unemployment in India.

\section{References}

Anand, N. (2018), "Everything you need to know about the massive crisis brewing in India's financial markets", Quartz India, Retrieved September 25 2018, from https://qz.com/india/1401032/why-the-ilfs-default-is-spooking-india/ 
BJP

(2014),

"Manifesto

for

2014",

available

at: https://www.bjp.org/en/manifesto?archives=1 (accessed 26 April 2020).

BJP (2019), “BJP Manifesto 2019”, available at: https://www.bjp.org/en/manifesto2019 (accessed 26 April 2020).

Business Today (2018), "Govt. has written off `2.4 lakh crore bad loans in three years, govt. tells parliament", Retrieved April 4 2018, from https://www.businesstoday.in/current/economy-politics/govt-has-written-off-rs-2.4lakh-crore-bad-loans-in-three-years/story/274077.html.

Digital India (2015), "Digital India Programmes", available at: https://digitalindia.gov.in/content/early-harvest-programmes (accessed 26 April 2020).

Global Findex (2018), "Database, 2017", World Bank, March, 2018, available at: https://globalfindex.worldbank.org. (accessed 26 April 2020).

Goods and Services Tax Council (2017), "GST Rate Changes", available at: http://gstcouncil.gov.in/sites/default/files/ready-reckoner/GST-rate-changes2809.pdf (accessed 26 April 2020).

Habib, I. (2019), "Government has deceived people, says historian Irfan Habib”, The Times of India, Retrieved August 5 2019, from https://timesofindia.indiatimes.com/india/government-has-deceived-people-sayshistorian-irfan-habib/articleshow/70541253.cms.

Human Rights Watch (2019), "World Report 2019", available at: https://www.hrw.org/world-report/2019/country-chapters/india (accessed 26 April 2020).

INC (2014), "Manifesto 2014", available at: https://www.inc.in/en/media/press-releases/incmanifesto-2014 (accessed26 April 2020).

INC (2019), "Manifesto 2019", available at: https://cdn.inc.in/manifestos/pdf_documents/000/000/005/original/English_Manifes to_MobilePDF_1April19-1.pdf?1554201123 (accessed 26 April 2020).

Jinoy, J. P. (2019), "Resignations in the IAS. What is troubling India's elite officers?", The Hindu, Retrieved $\quad$ September 27 2019, from https://www.thehindubusinessline.com/blink/know/resignations-in-the-ias-what-istroubling-indias-elite-officers/article29528239.ece.

Kumar, R. (2019), "Citizenship and Journalism under Constant Threat: Ravish Kumar at Magsaysay Award", available at: https://m.youtube.com/watch?v=QwFse9U3r_8 (accessed 26 April 2020).

Laffer, Arthur (1979), "Laffer curve", available at; https://en.wikipedia.org/wiki/Laffer_curve. (accessed 26 April 2020).

Ministry of Finance (2003), "Fiscal Responsibility and Budget Management Act, 2003", available at: https://dea.gov.in/sites/default/files/FRBM\%20Act\%202003\%20and\%20FRBM\%2 0Rules\%202004.pdf (accessed 26 April 2020).

Ministry of Finance (2019), "Union Budget of India, 2019-20”, Retrieved July 5 2019, from https:/www.indiabudget.gov.in/.

Ministry of Finance (2019), "RBI provisional data on global operations, as on 31.3.2019, the aggregate amount of gross NPAs of PSBs and Scheduled Commercial Banks (SCBs) were `8,06,412 crore and `9,49,279 crore respectively", available at: 
https://pib.gov.in/newsite/PrintRelease.aspx?relid=190704 (accessed 26 April 2020).

Ministry of Home Affairs (2015), "Foreign Contribution Regulation Amendment Rules, 2015", available

at: https://fcraonline.nic.in/home/PDF_Doc/doc00600120151214130739.pdf (accessed 26 April 2020).

Mohammad, I. S. (2019), "Madras High Court Chief Justice Tahilramani to quit", The Hindu, Retrieved September 6 2019, from https://www.thehindu.com/news/national/tamil-nadu/madras-high-court-chiefjustice-tahilramani-to-quit/article29355280.ece.

MOSPI (2019), “Annual Report, 2018-19”, available at: http://www.mospi.gov.in/sites/default/files/publication_reports/Annual\%20Report \%202018-19\%20Eng\%20Web.pdf (accessed 26 April 2020).

MOSPI (2019), "Periodic Labour Force Survey, Annual Report, July 2017-June 2018)", available http://www.mospi.gov.in/sites/default/files/publication_reports/Annual\%20Report \%2C\%20PLFS\%202017-18_31052019.pdf (accessed 26 April 2020).

Mukherjee, P. (2019), "India will become USD 5 trillion economy because of strong foundation laid by previous govt: Pranab Mukherjee", India Today, Retrieved July 19 2019, from https://www.indiatoday.in/india/story/pranab-mukherjee-1571099-2019-07-19.

Narayanan, D. (2019), "Central funds to states may be cut to create internal security fund", The Economics Times, Retrieved September 23 2019, from https://economictimes.indiatimes.com/news/defence/nk-singh-headed-financecommission-working-on-proposal-cabinet-cleared-enabling-approvals-on-july17/articleshow/70384389.cms?from $=$ mdr.

NSSO (2014), "Employment and Unemployment Situation in India, NSS $68^{\text {th }}$ round, (July 2011- June 2012)", available at: http://mospi.nic.in/sites/default/files/publication_reports/nss_report_554_31jan14.p df (accessed 26 April 2020).

Panagariya, A. (2017), "India 2031-32: Vision, Strategy and Action Agenda", available at: https://india.uitp.org/articles/india-niti-aayog-vision-2031-32 (accessed 26 April 2020).

Raghavan, S. (2019), "GST return form too complex to meet filing deadline", The Hindu, Retrieved September 3 2009, from https://www.thehindu.com/business/gst-returnform-too-complex-to-meet-filing-deadline/article29325413.ece.

Rautray, S. (2019), "Government in SC on 10\% EWS quota: 50\% ceiling can be broken", The Economic Times, Retrieved August 1 2019 from https://economictimes.indiatimes.com/news/politics-and-nation/will-decide-ifpleas-against-10-quota-are-to-be-referred-to-constitution-bench-sayssc/articleshow/70453115.cms?from $=$ mdr.

RBI (2018), “RBI's Annual Report for 2017-18”, available at: www.rbi.org.in (accessed 26 April 2020).

RBI (2019), "RBI Central Board accepts Bimal Jalan Committee recommendations and approves surplus transfer to the Government" "Economic Capital Framework", available at: https://www.rbi.org.in/Scripts/BS_PressReleaseDisplay.aspx?prid=47983. (accessed 27 April 2020) 
RBI (2019), “RBI's Annual Report for 2018-19”, available at: www.rbi.org.in (accessed 26 April 2020).

Roy, A. (2019), "Budget 2019: In a first, India to issue sovereign bonds in global market", Business Standard, Retrieved July 5 2019, from https://www.businessstandard.com/budget/article/budget-2019-in-a-first-india-to-issue-sovereign-bondsin-global-market-119070501565_1.html.

SDDS (2018), "SDDS Annual Report, 2018: Undue delays in data dissemination from government agencies", available at: https://dsbb.imf.org/content/pdfs/AnnualReports/2018/IND_SDDS_AR2018.pdf (accessed 26 April 2020).

Sharma, M. (2019), "Auto sector crisis: 2.30 lakh jobs lost as industry faces worst crisis in 20 years", India Today, Retrieved August 13 2019, from https://www.indiatoday.in/business/story/auto-sector-crisis-two-lakh-jobs-industryworst-crisis-20-years-1580386-2019-08-13.

Sharma, S. (2019), "Annihilation of Caste System is a must to make India strong and secular", in Edulearn 19 Proceedings, $11^{\text {th }}$ International Conference on Education and New Learning Techniques, 1-3 July 2019, IATED Academy, Palma, Mallorca, Spain, ISBN: 978-84-09-12031-4, ISSN: 2340-1117, pp. 10648-10652, available at: https://library.iated.org/view/SHARMA2019ANN,

Shyam, A. (2019), "India's consumption story losing the plot", The Economic Times, $\begin{array}{llll}\text { Retrieved } & \text { May } & \text { 2019, from }\end{array}$ https:/economictimes.indiatimes.com/news/economy/indicators/indiasconsumption-story-losing-the-plot/articleshow/69210037.cms.

Singh, M. (2019), "Economy in prolonged slowdown', Hindustan Times, Retrieved September 1, 2019, from https://www.hindustantimes.com/india-news/economy-inprolonged-slowdown-manmohan-singh/story-a6XPtnToGJXn1RXwuhp5nJ.html.

The Economic Times (2006), "Budget '06: Full text", Retrieved February 28 2006, from https://economictimes.indiatimes.com/news/economy/policy/budget-06-fulltext/articleshow/1432307.cms.

The Economic Times (2019), “Jalan panel wants transfer of RBI's surplus reserves over 35 years", $\quad$ Retrieved July 18 2019, from https:/economictimes.indiatimes.com/news/economy/policy/jalan-panel-finalisesreport-on-rbi-capital-recommends-surplus-transfer-to-govt-in-3-5years/articleshow/70258737.cms.

The Hindu (2014), "Economic Survey 2013-14: Full text”, Retrieved July 9 2014, from https://www.thehindu.com/news/resources/economic-survey-201314 fulltext/article6192986.ece.

The Hindu (2019), "BSNL plans to reduce its employees", Retrieved September 92019 , from https://www.thehindu.com/news/national/kerala/bsnl-plans-to-reducecontract-employees-by-30/article29372730.ece.

World Bank (2017), "World Bank Indicators- Trading Economics", available at: www.tradingeconomics.com/india/news (accessed 26 April 2020) 